\title{
Factors Influencing Logistics Outsourcing in Pakistan
}

\author{
Kanwar Uzair ${ }^{1 *}$, Danish Ahmed Siddiqui ${ }^{2}$ \\ ${ }^{1}$ Research Scholar, Karachi University Business School, University of Karachi, PAKISTAN \\ ${ }^{2}$ Associate Professor, Karachi University Business School, University of Karachi, PAKISTAN \\ *E-mail for correspondence: kanwar.uzair@gmail.com
}

https://doi.org/10.18034/abr.v8i1.3

\begin{abstract}
The Freight Forwarding and Logistics industry plays a vital role in the overall economy of Pakistan. The purpose of this study is to determine the factors that influence for outsourcing the logistics and at the same time performance of outsourcing has been evaluated with respect to Karachi, Pakistan. Three factors identified as Low Human Assets, Low Physical Assets and Partnership, all have a positive impact on logistics outsourcing and the firm performance especially in terms of Financial Benefit. Online survey was conducted and the data was obtained from a sample size of 165 from the seniority level of the manufacturing industry in Karachi. We measure the inner model by Smart PLS software to indicate the reliability of all factors that significant impact on logistics outsourcing practices. Reliability test was also performed which showed that our study is significant.
\end{abstract}

Key words: Outsourcing, Low Physical Assets, Low Human Assets, Partnership, Logistics Outsourcing Practices and Financial Benefit

\section{INTRODUCTION}

The ability to obtain the goods and distribute it around the world is the structure of the Supply Chain. Strategically it competes on the basis of cost, service, time and transportation that play significant role in supply chain. Third party logistics providers working as an independent organization, carry all the responsibilities of transportation from acquiring of goods to deliver to final customer that is now. Outsourcing success is the dynamic factors of the business function since after the revolution in information technology people are align to each other through knowledge sharing which significantly integrate skill workforce with low physical assets and high transaction uncertainty. It is important in outsourcing that partners share the abilities on each element to work effectively. Logistic functions are outsourced to the external service providers with the aim of acquiring technological, economic and strategic advantages (Venkatraman, 1992). Despite of the significance, now it is considered as the mandatory function of the business.

\section{Problem Statement}

In the complex and massively challenging market environment, organizations now have difficulties of improving quality, bringing down costs and addressing individual needs. Hence, now organizations are starting to focus on logistics as an essential mean to achieve and sustain competitive advantage. For firms, extending current or establish new logistics capabilities is an approach to create value for customers and themselves (Esper, Fugate \&Sramek, 2007; Mentzer, Min \& Bobbitt, 2004).

Hsiao et al. (2010), pointed out that companies outsourced logistics services because they do not own suitable transport vehicles, which is one of the factors lacking in the firm's physical assets in their case study analysis

Knemeyer and Murphy (2005) states that there has been very little research concerning the activities that might influence the performance of logistics outsourcing relationships.

Bourlakis and Melewar (2011) examine managing operations has become very challenging for most corporations considering the vast range of logistics functions.

The birth of logistics can be traced back to ancient war times of Greek and Roman empires where soldiers are assigned to provide services of supply and distribution of resources that enable soldiers to move forward from base position to forward line. After World War II logistics evolved greatly that consider as an art and science. Now organization term logistics as providing the right type of products and or services at the right price, at place, time in the right condition. 
The concept of logistics is based on systematic approach that performs functions in the systematic way starting from the movement of material from supplier to end user with the aim of achieving customer satisfaction.

\section{Research Objective}

The main purpose of the study is to examine the influential factors that outsource logistics activities which impact on firm performance.

\section{Research Questions}

Following are the research questions which study to be done.

What are the factors that influenced to outsource logistics with extent to logistics outsourcing practices?

What is the effect of logistics outsourcing practices that impact on logistics outsourcing performance?

\section{Significance of the Study}

The findings of this study will provide an insight to the supply chain manager to outsource the functions of logistics that significantly impact to operational cost and time compression of manufacturing firms that like other firm's resources whether logistics could be an importance source to sustainable and improve performance.

\section{Limitation of the Study}

The main objective of the research is to explore the areas with different aspects and to find out new dimension which provide guidance to the people but to achieve that there are the constraints that need to be consider. The first and most precious is the time constraint that limits our self to work under it, secondly region of the study to work on it. It is very important to understand the respondent of the research for generic feedback as well as the sample size that limit to find out the results which are not efficient to measure the study.

\section{LITERATURE REVIEW}

\section{Theoretical Background}

The outsourcing of logistics functions to partners, known as "third-party logistics providers", has increasingly become a powerful alternative to the traditional, vertically-integrated firm. To obtain competitive advantage, Resource based view (RBV) has gain the dominance in the organization's strategic management approaches, which began with Werner felt in the 1980. It contends that by optimal utilization of resources and competence, Companies may obtain and sustains competitive advantage (Day, 1994; Wernerfelt, 1984).

However, Barny 1991 explore that logistics capability is that part of firm's resources which allow it to conceive of and implement strategies that improve efficiency and effectiveness. According to Dekkers (2011) and Wernefelt (1984), the RBV defined resources as tangible and intangible assets that are rooted half-permanent to a firm. Barney (1991), however, moved the emphasis from the organizational view to the firm's goal of reducing the uncertainty and dependency on other organizations to reduce the risk for its survival.

\section{Transaction Cost Economics Theory}

William 1975 stated that in TCE approach, the properties of the transaction determine what establish the most competent governance structure-market, hierarchy or alliance. The primary factors producing transactional difficulties include bounded rationality, opportunism, small numbers bargaining, and information impactedness. Bounded rationality and opportunism are behavioral assumptions. Bounded rationality refers to the rational limitations of the human mind, which increases the difficulties of understanding fully the difficulties of all possible decisions. Opportunism refers to decision makers acting with cunning, as well as out of self-interest. Small numbers bargaining refers to the degree to which the buyer has alternative sources of supply to meet its requirements. Information impactedness refers to the presence of information asymmetries between the buyer and supplier, which means that either party may have more knowledge than the other. These transaction difficulties and associated costs increase when transactions are characterized by asset specificity, uncertainty and infrequency.

Asset specificity refers to the level of customization supplementary with the transaction. Highly asset-specific investments represent costs that have little or no value outside the transaction. The costs can be in the form of physical asset specificity (level of product or service customization), human asset specificity (level of specialized knowledge involved in the transaction) or site specificity (location). Asset specificity can be non-specific (highly standardized), idiosyncratic (highly customized to the organization) or mixed (incorporating standardized and customized elements in the transaction). According to Klein et al., 1978 TCE affirms that the potential for opportunistic behavior is most likely when an exchange requires one or both parties to make significant transaction-specific investments, since such investments create quasi-rents that are subject to the holdup problem. When asset specificity and uncertainty is low, and transactions are relatively frequent, transactions will be ruled by markets. Hierarchical governance occurs when uncertainty and high asset specificity lead to transactional difficulties. Medium levels of asset specificity lead to mutual relations in the form of co-operative alliances between the organizations or intermediate governance.

\section{Logistics Outsourcing}

Companies can either keep logistics functions in house or contract them out. The decision process is based on an evaluation of the costs and benefits of outsourcing. Lankford and Parsa (1999) stated that outsourcing is 
usually supported by many factors in all organization levels. The decision to outsource should take account of many issues: scale of economy, outsourcer expertise, strategy, the need for cost savings, and accountability with greater control of operating costs, moving from fixed into variable costs, and quality factors

Crum and Allen (1997); Lieb and Miller (2002) suggest that a user could reduce capital investment in logistics facilities, focus on core activities, reduce inventory, improved response rate to marketing and minimize logistics costs through outsourcing.

Several studies have been completed on various aspects of outsourcing. Campbell (1995) indicated that a planned strategy for outsourcing has the potential to deliver a competitive advantage through allowing the organization to focus on core activities. This planned strategy involves measuring the willingness of the organization to introduce outsourcing, as well as identifying the activities which offer the best potential to the organization.

\section{Influential Factors of Logistics outsourcing}

Power, Sharafali and Bhakoo (2007) examine that majority of the research in this area has centered on the type of activities outsourced, the reasons behind these decisions and on benefits of logistics activities. Gattorna and Hargreaves, 1991 mentioned that the factors that influence to outsource are categorized into two aspects; control and physical. Control aspects involves the management activities along with the performance measurement in contrast to physical aspect it involves the operation ability which focus on lean manufacturing to integrate product stabilization.

Khosrowpour, Gunderman, Subramanian (2000) explore the perception of employee with respect to outsource of Information system that workforce reduction are an issue for the client as well as the outsourcing vendor. Once the rumors have been imposed of outsourcing of Information system, naturally it started fear and terming of responsibility which significantly impact to the organization.

Moad (1991) points out, outsourcing vendors reputation are not the best with the professionals; many employees see these firms as threat to their security. Frequently, outsourcing vendors will go over management head directly to corporate executives. This method often used by vendors because they realize that management is generally not receptive to what the vendor has to offer. Employers who are in the lower ranks of the organization are also uncomfortable with the idea of being taken over and becoming a pawn in a business transaction.

Large (1991) states that an organization focusing in information technology can gain competences in two different aspects. First, the economies of scale associated with running large operations cuts down on per unit cost associated with computing. Second, the knowledge base of experience and expertise in the company results in a more efficient and effective organization.
Gupta and Gupta (1992) suggest that the economic losses tangled to human resources are significant, but are rarely revealed by companies. However, Buck-Lew 1992 believes that more control is achieved through the use of an outside party.

Lasher, lves and Jarvenpaa (1991) define partnership as "a co-operative relationship in which parties are equally responsible for the business success and failure of the product or project. It also argue that partnership between a firms information group and either its supplier (external partnership) or its internal customers (internal partnership) can play an important role in the effective acquisition and management of emerging information technologies. Furthermore partnership allows both the parties to work on mutual understanding by setting up key organizational objectives and competitive advantage of their respective industries.

Gummesson (1987) narrates the supplier and customer relationship through the Network/ Interaction relationship theory that states that "all activities by the firm to build maintain and develop customer relations". The network/interaction theory emphasize on long term relationship for buyer and seller.

\section{Logistics outsourcing practices}

In modern technological world many companies aiming to achieve the higher market share by taking advantage of lean manufacturing and sourcing efficiencies. Nowadays the key element of business performance is the role of Supply Chain Management. As SCM is becoming the most complicated and the gap between what companies want to achieve and what they can do in house continues to grow, the rationale for outsourcing to Third party logistics providers (3PLs) is further justified. Therefore, there is currently a trend among manufacturing firms of outsourcing those products and activities that are outside the company's core business.

Novack, Rinehart and Wells (1992), updated Bowersox's logistics framework by suggesting that optimization of the logistics functions takes precedence over the optimization of individual logistics activities. According to Novack framework logistics activities divided into two categories; the first category involves the "Physical activities that are required to create form, time and quantity utilities of customer need. These activities cover inventory, transportation, and customer service operation. The second category involves the "Transaction activities that follow or initiate the physical activities previously presented. The activities in this category are centered on transaction negotiation areas (i.e the interaction between firms through the purchasing of inbound materials, supplies, and products) and order cycle management areas (i.e. the management and control of information flows necessary to create customer service in the logistics system). 


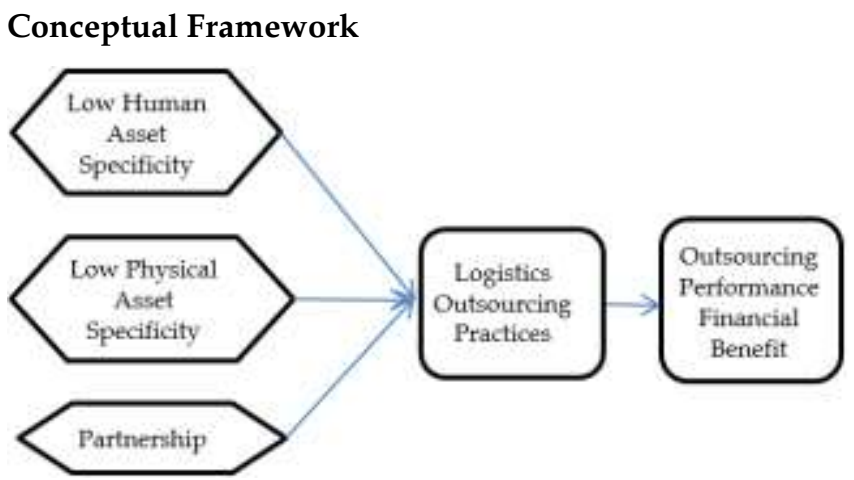

\section{Hypothesis Development}

Razzaque and Sheng (1998) suggested that, firm outsource logistic activity and depend upon logistic service that does not possess the required asset to perform the logistic activity. The low physical asset is a major factor firm outsources the logistic activity (Vivaldini and Pires 2013). Hypothesis shows that low physical asset positively affect outsource logistic activity.

$\mathrm{H}_{1}$ Low physical assets positively affect the extent of logistics outsourcing practices.

Hsiao et al. (2011) states that the decision outsources the logistic are influence by investment on employees, training and development. Kremic et al. (2006) asserted that firm outsources their function when they do not have enough expertise to perform. Greaver (1999) states that lack of specialist staff reason to outsource the logistic activity. As such, firm have strong human asset, perform by itself whereas firm have low human asset go for outsourcing. These argument support positive relation between low human asset and outsource logistic activity.

$\mathrm{H}_{2}$ Low human assets positively affect the extent of logistics outsourcing practices.

Lasher, Lves and Jarvenpaa 1991 define partnership as "a co-operative relationship in which parties are equally responsible for the business success and failure of the product or project. It also argue that partnership between a firms information group and either its supplier (external partnership) or its internal customers (internal partnership) can play an important role in the effective acquisition and management of emerging information technologies. Furthermore partnership allows both the parties to work on mutual understanding by setting up key organizational objectives and competitive advantage of their respective industries.

$\mathrm{H}_{3}$ Lower Partnership affects the extent of logistics outsourcing practices.

Warehouse service is one of the part of logistic activity discuss by Cho et al. (2008). Zhang (2007) asserted firm outsources warehouse services to improve firm performance. Hsiao et al. (2011) asserted that packaging and handling outsource activity are influential factor that improve the firm performance. Sahay and mohan (2006) state that $29 \%$ of packaging and handling activity outsource is a strategy of supply chain to improve firm performance. Gol and Catay (2007) state that inventory management is one of the common activity to outsource to improve the firm efficiency. These argument support positive relation between logistics outsourcing practices and outsource logistic performance.

$\mathrm{H}_{4}$ Extent of Logistics outsourcing practices affects the logistics outsourcing performance.

\section{Research Methodology}

The aim of the study is to examine the influential factors of logistics outsourcing which indulge the management for decision making. Since research is purely based on primary data. Therefore, with purpose of information collection, a questionnaire survey was directed to a multi- industry of manufacturing firms in different region of Pakistan.

\section{Research Design}

A survey population was selected from manufacturing firms in Pakistan belong to multiple industries. In order to examine the influential factors of logistics outsourcing, questionnaires were sent to Chief Executive officers, Managing Directors, departmental heads and departmental Managers since such people were considered to have relevant knowledge of firms' strategies and were considered appropriate respondents to provide relevant information. The analysis of the data would be measured through the qualitative technique.

\section{Face and Content validity}

When it comes to questionnaire adaption it is mandatory to measure the quality and validity of the questionnaires from the concern professionals. The validity of this questionnaire has been approved from the supply chain professional and the relevant teacher of supply chain.

\section{Target Population}

The different manufacturing companies who use outsource logistic and managers from supply chain, procurement, purchasing, contract manufacturer management and planning located in Karachi are the target population of this research.

\section{Sample Size}

A model based on the resource based view and transaction cost theory illustrates the hypothetical connections among these variables. The data gathered from the survey were analyzed using Smart PLS software. A response rate of $41 \%$ out of the 400 firms selected was achieved and fixed as the empirical data for this study.

\section{Data Collection}

The tool which is designed for the gathering of data is a questionnaire. In addition, the questionnaire is generated on the method of Five-Step Likert Scale level which includes Strong disagree, Disagree, Neutral, Agree and Strongly 
Agree (Likert, R., 1932). Besides, the designed questionnaire is modified or else adapted from many publications.

\section{Statistical Technique for Data analysis}

The software used for the analysis of collected statistics for this study is SPSS Moreover, the statistical examinations executed in this study by using Smart PLS software.

Independent Variables (IDV's)

- Low human assets Specificity

- Low Physical Asset Specificity

- Partnership

Dependent Variable (DV)

- Financial Benefit

Moderator

- Logistics Outsourcing Practices.

\section{FINDINGS OF THE STUDY}

For initial testing we used SPSS for pilot testing and data screening. Smart PLS 3.2.4 used for testing the content validity, reliability, convergent validity and discriminant validity followed by the Heterotrait-Monotrait Ratio (HTMT) (Hensly, 2015).

\section{Measurement of Outer Model}

The validity and reliability of outer model was established before the examination of proposed hypothesis by using the Smart PLS 3.2.4 software. Data of analysis were describes in the following sections. Three criteria were used to validate and reliability of data of outer model that includes content validity, convergent validity and discriminate validity.

Composite Reliability: The composite reliability of the whole measurement model is analyzed by cross loadings and actual interpretation of confirmatory factor analysis (CFA). According to Chin (1998) and Heir et al (2013) strong factors loading within the construct model is must and if found any construct is weak in construct model it should have eliminate from the model to improve the outer model. The threshold of the composite reliability is greater than 0.7, which consider a strong model and construct. According to the below Figure 1 mostly loading are greater than 0.7 so it represents this model is with strongly loading construct.

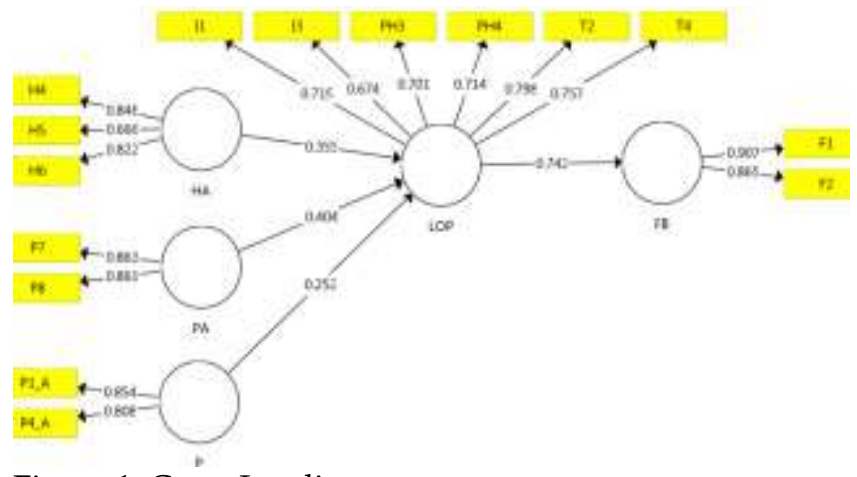

Figure 1: Cross Loading
Convergent Validity: The measurement of convergent validity would be done in three sections. First strongly construct between the factors loading which threshold is greater than 0.7Gefen and Straub (2005), Second calculate the average variance extracted (AVE) which threshold accepted is greater than 0.5 (Fornell and Larcker (1981) and third is composite reliability (CR) should be 0.7 or greater than. Table 1 shows all the above assumptions correct.

Table 1: Construct Reliability

\begin{tabular}{|c|c|c|c|c|}
\hline Constructs & $\begin{array}{c}\text { Cronbach's } \\
\text { Alpha }\end{array}$ & rho_A & $\begin{array}{c}\text { Average } \\
\text { Composite } \\
\text { Rariance } \\
\text { Extracted } \\
\text { (AVE) }\end{array}$ \\
\hline FB & 0.728 & 0.743 & 0.879 & 0.785 \\
\hline HA & 0.691 & 0.736 & 0.824 & 0.612 \\
\hline LOP & 0.823 & 0.827 & 0.871 & 0.531 \\
\hline P & 0.554 & 0.56 & 0.817 & 0.691 \\
\hline PA & 0.654 & 0.654 & 0.853 & 0.743 \\
\hline
\end{tabular}

Discriminate Validity: There are two different criteria in which we measure the discriminant validity. First Fornell and Larcker (1981) which shows the correlation matrix model basically shows the correlation between the variables. Tables 2 represent the correlation of discriminate validity in the form of diagonal line. SecondHeterotraitMonotrait Ratio (HTMT), in HTMT the values should be less than 1 which shows the perfect result of thesis. Table 2 represents the HTMT values of the model.

Table 2: Heterotrait-Monotrait Ratio (HTMT)

\begin{tabular}{|c|c|c|c|c|c|}
\hline & FB & HA & LOP & P & PA \\
\hline FB & & & & & \\
\hline HA & 0.675 & & & & \\
\hline LOP & 0.927 & 0.92 & & & \\
\hline P & 0.546 & 0.935 & 0.942 & & \\
\hline PA & 0.702 & 0.842 & 0.977 & 0.711 & \\
\hline
\end{tabular}

As per the above data all the values are less than 1 which shows that all the variables are accepted and these are confirmatory discriminate validity of this model Henseler et al (2015).

\section{Model Evaluation and Hypothesis Testing}

The hypothesis testing and model evaluation performed by PLS structure equation modeling Ringle et al. (2015). The results are presented in order to investigate the possible problem, the result shows that the value of low human assets specificity, low physical asset specificity, and partnership are significant and positive with logistics outsourcing practices i.e $(0.001),(0.000)$ and $(0.009)$ respectively. It also states that the value of logistics outsources practices is (0.000) with effect to financial benefit that means $\mathrm{H} 1$ and $\mathrm{H} 2$ are less than $\mathrm{p}<0.05$ which is significant and positive relationship with outsourcing performance, 


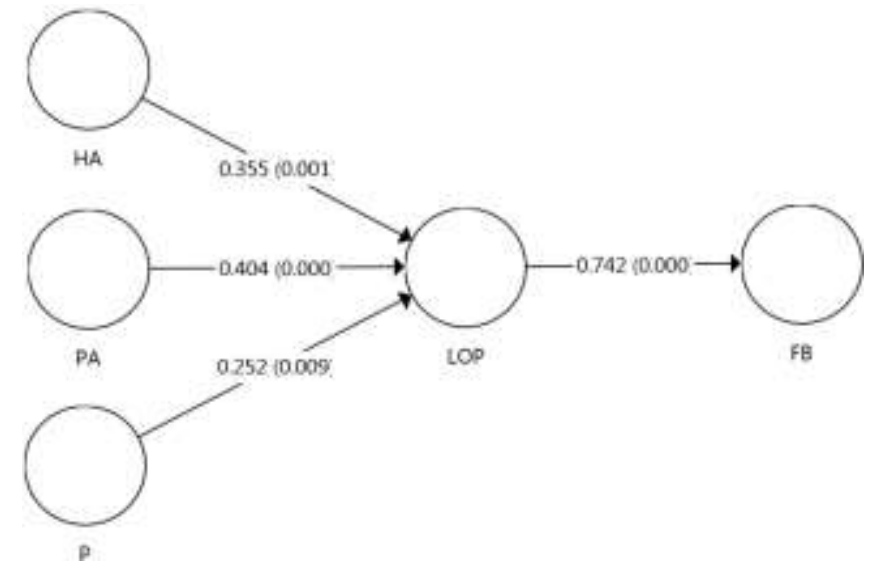

Figure 2: SEM output (factors loading and T- Statistics)

According to the above figure of SEM model it represents the relationship between the independent variables to dependent variables by the medium of logistics outsourcing practices. The beta values of all the independent variables is positive which significantly impacting on logistics outsourcing practices and it also states the effect of LOP to financial benefit is positively that means that organization closely look out the logistics practices while outsource the logistics department. The beta value of the low physical asset is on higher side comparatively to partnership and low human asset so firms need to consider more consciously on the resources that organization required because without updated and technological resources firms could not compete with the market.

Table 3: Hypothesis Testing and Results

\begin{tabular}{|c|c|c|c|c|c|}
\hline Hypothesis & Estimates & $\begin{array}{c}\text { Standard } \\
\text { Deviation }\end{array}$ & $\begin{array}{c}\mathrm{T} \\
\text { Statistics }\end{array}$ & $\begin{array}{c}\text { V Values } \\
\text { Decisions }\end{array}$ & \\
\hline HA -> LOP & 0.355 & 0.103 & 3.446 & 0.001 & Accepted \\
\hline LOP -> FB & 0.742 & 0.054 & 13.836 & 0.000 & Accepted \\
\hline P -> LOP & 0.252 & 0.096 & 2.617 & 0.009 & Accepted \\
\hline PA -> LOP & 0.404 & 0.067 & 6.052 & 0.000 & Accepted \\
\hline
\end{tabular}

As per the above testing of hypothesis the relationship between the variables have positive relationship and the $p$ value of all the variables is less than 0.05 which has been confirmed that the variables that dig out for the study has significantly impact on the firm performance as we can see that the value of LOP with the relationship to Financial Benefit is (0.000) which shows the strong relationship of logistics outsourcing practices indulge to the financial benefit to the firms. Therefore we conclude that the hypothesis of the study has been accepted so it would recommend the factors of low human asset specificity, low physical asset specificity and partnership significantly impact on logistics outsourcing which definitely impact to the performance of the firm financially.

\section{Discussion}

One of the purposes of this research was to examine factors influencing logistics outsourcing along with their
Performance. Their research found that the three main factors that push the organization to outsource the logistic segment that include low human asset specificity, low physical asset specificity and partnership. These are the factors that play a vital role in the organization especially the human resources which is the big asset of the firm that generate revenue. Nowadays partnership is becoming the key element of outsourcing because without connecting business could not run successfully. In this modern world working independently is not the key to success we need to co-operate with our strategic partners which help to achieve the competitive edge.

The findings of our research reveal that the influential factors investigated in this study have significant effect on outsourcing success. Findings further reveals that low human asset specificity, low physical asset specificity and partnership have significant impact on performance of outsourcing especially financially perspective. The possible reason for the acceptance of almost all hypotheses is that organizations in Pakistan, consider logistics as an important strategic mean after the such great game changer of CPEC project that cater almost $80 \%$ of the logistics activities that open the route for exporting the goods to different region of the world. CPEC project has now greatly impact to the Pakistan economy, the supply and demand of the goods now has been increased because of the building of the hub of transportation that reveal the supply of the goods through by road conveniently. The infrastructure of the transportation has been change especially Gawadar port which has become the central hub of Asia for transportation of the goods that require skilled workforce, advanced technological resources with strong co-ordination with the vendors that build up the trust to work effectively and all these activities significantly impact to the economy of the country. The another reason of the significant of the variable that Pakistan is becoming the trading country which mainly depend on logistic service providers firms to get the raw material around the world, As per the Logistics Performance Index Pakistan ranked $68^{\text {th }}$ Position out of 160 countries in 2016 which states that Pakistan increasing the inbound activities on a very large scale.

\section{CONCLUSION}

This study has evaluated the key factors that influence the extent of logistics outsourcing practices and how the extent of these practices affects logistics outsourcing performance. LOP has been measured through the four factors that is transportation, warehouse, packaging and handling and inventory management. Three factors were studied to determine whether or not they influence the extent of logistics outsourcing practices-low of human assets, low of physical assets and partnership as elaborated by $\mathrm{Xu}$ (2009). The extent of logistics outsourcing practices is used that provide financial benefit the organizations that make outsourcing performance effectively. 


\section{POLICY IMPLICATIONS}

This study suggest following managerial implication and policy recommendation for Top Managers, Organizational owner/decision makers and regulatory bodies.

- Top management should pay more attention on key human workforce and these should perceive as an important assets to firm rather than liability.

- Organizations need to more focus on strategic coordination and must share all information within the organization for smooth operations, since it is not only support other logistics operation but it may improve other department of organization.

- Manager should expend effort to develop and enhance key logistics capabilities in order to achieve sustainable performance.

- The development of key strategic physical asset require people to change by putting aside old ideas and need to look new ways of doing thing.

- The role of Government and regulatory bodies is also important since they can implement suitable policies and can develop such infrastructure that help manufacturing firm to develop their logistics capabilities, since these organization are the stake holder of economy.

- There should be a collaborative committee in the organization that must ensure to conduct for sharing different experiences faced which can improve the performance organization.

\section{Future Research}

Although this study has made significant contribution to the knowledge base on logistics outsourcing by empirically testing the relationship between influential factors and performance of logistics outsourcing practices, but like other studies this research has some limitations. Few influential factors with the extent of logistics outsourcing practices and firm's performance variables have investigated but both of these have multiple facets and it is beyond the scope of single research to undertake such task of investigating numerous facets simultaneously. Other logistics practices element such as Process capability, Lead time, supply chain network, cost effective, responsiveness to market, operational capability, demand oriented and supply oriented capability need to be examined. Similarly firm performance in this study has focus on operational level. Other operational performance variables are further need to investigate.

\section{REFERENCES}

Bardi E.J. and M. Tracey. (1991). "Transportation Outsourcing: A Survey of US Practices." International Journal of Physical Distribution and LogisticsManagement 21 (3).15-21.

Barney, J. (1991), "Firm resources and sustained competitive advantage", Journal of Management, Vol. 17 No. 1, pp. 90-120.
Browne M. and J. Allen.(2001). "Logistics out-sourcing."In Brewer A.M., K.J. Button and D.A. Hensher (eds.), Handbook of Logistics and SupplychainManagement. New York: Pergamon.

Campbell, J.D. (1995), “Outsourcing in maintenance management: a valid alternative to self-provision", Journal of Quality in Maintenance Engineering, Vol. 1 No. 3, pp. 18-24.

Clark, T., Zmud, R., McCray, G., 1996. The outsourcing of information services: transforming the nature of business in the information industry. Journal of Information Technology 10, 221-238.

Crum M.R. and B.J. Allen.(1997). "A Longitudinal Assessment of Motor Carrier-Shipper Relationship Trends, 1990 vs. 1996."Transportation Journal 37 (1).5-17.

Grover, V., Malhotra, M., 2003. Transaction cost framework in operations and supply chain management research: theory and measurement. Journal of Operations Management 21, 457-473.

Gummesson. E The new marketing- developing long-term interactive relationships. Long Range Planning. 20, 4 (1987). $10-20$

Halldórsson, A. and Skjøtt-Larsen, T. (2004), "Developing logistics competencies through third party logistics relationships", International Journal of Operations and Production Management, Vol. 24 No. 2, pp. 192-206.

Harrigan, K.R., 1986. Matching vertical integration strategies to competitive conditions. Strategic Management Journal 7, 535-555.

Hsiao, H.I., Vorst, J.G.A.J.v.d., Kemp, R.G.M. and Omta, S.W.F. (2010b), "Developing a decision making framework for levels of logistics outsourcing in food supply chain networks", International Journal of Physical Distribution and Logistics Management, Vol. 40 No. 5, pp. 395-414.

Klein, B., Crawford, R., Alchian, A., 1978. Vertical integration: appropriable rents and the competitive contracting process. Journal of Law and Economics 21, 279-326

Lankford, W.M. and Parsa, F. (1999), "Outsourcing: a primer", Management Decision, Vol. 37

Lasher, D.R: Ives, B: and Jarvenpaa, S.L. USAA-IBM partnership in information technology: managing the image project. MIS Quarterly, 15, 4 (1991), 551-565.

Leahy S.E., P.R. Murphy and R.F. Poist. (1995). “Determinants of Successful Logistical Relationships: A Third-Party Provider Perspective." Transportation Journal 35 (2).5-13.

Lieb R.C. and H.L. Randall. (1999). "1997CEOPerspectives on the Current Status and Future Prospects of the Third Party Logistics Industry in the United States. "Transportation Journal 39 (3).28-41.

Lonsdale, C. (1999), "Effectively managing vertical supply relationships: a risk management model for outsourcing", Supply Chain Management: An International Journal, Vol. 4 No. 4, pp. 176-83. No. 4, pp. 310-6.

Mckenna. R. The Regis Touch. Readine, MA: Addison-Wesley, 1985.

Rindfleisch, A., Heide, J.B., 1997. Transaction cost economics: past, present, and future applications. Journal of Marketing $61(4), 30-54$. 
Shelanski, H., Klein, P.G., 1995. Empirical research in transaction cost economics: a review and assessment. Journal of Law, Economics, and Organization 11, 335-361.

Stratman, J.K., 2008. Facilitating offshoring with enterprise technologies: reducing operational friction in the governance and production of services. Journal of Operations Management 26 (2), 275-287.

TCE (Logistics 12)
Walker, G., Weber, D., 1987. Supplier competition, uncertainty and the make-or-buy decision. Academy of Management Journal 30, 589-596.

Williamson, O.E., 1975. Markets and Hierarchies. Free Press, New York.

www.bestlogisticsguide.com/logistics-history

$--0--$

Issue Link: https://doi.org/10.18034/abr.v8i1

Online Archive: https://abc.us.org/ojs/index.php/abr/issue/archive 